\title{
The nexus between an art experience and creative tourism
}

Tasmania's Museum of Old and New Art

Kim Lehman and Dirk Reiser

\section{OpenEdition}

\section{Journals}

Electronic version

URL: http://journals.openedition.org/tourisme/372

DOI: $10.4000 /$ tourisme.372

ISSN: 2492-7503

\section{Publisher}

Éditions touristiques européennes

Printed version

Date of publication: 1 December 2014

Number of pages: 19-32

ISSN: 2109-5671

\section{Electronic reference}

Kim Lehman and Dirk Reiser, "The nexus between an art experience and creative tourism », Mondes du Tourisme [Online], 10 | 2014, Online since 30 September 2015, connection on 14 November 2019. URL : http://journals.openedition.org/tourisme/372 ; DOI : 10.4000/tourisme.372

\section{(9) $\odot \Theta \Theta$}

Mondes du tourisme est mis à disposition selon les termes de la licence Creative Commons Attribution - Pas d'Utilisation Commerciale - Pas de Modification 4.0 International. 


\title{
The nexus between an
}

\section{art experience and creative tourism:}

\section{Tasmania's Museum of Old and New Art}

\section{Dr Kim Lehman}

Tasmanian School of Business and Economics, University of Tasmania. [kim.lehman@utas.edu.au]

\author{
Prof. Dirk Reiser \\ Rhine-Waal University of Applied Sciences \\ [d.reiser@cbs-edu.de]
}

\begin{abstract}
Résumé. Le secteur culturel est, de plus en plus souvent, appréhendé par les gouvernements comme un vecteur de croissance (touristique), notamment dans les sous-régions périphériques comme la Tasmanie où les industries dominantes de jadis ont disparu. Ce secteur peut être une source de créativité locale, d'intégration sociale et d'attractivité touristique. Dans certains cas, la création d'une entité culturelle iconique sert ce même but, avec un faible investissement public. C'est le cas notamment du Museum of Old and New Art (MONA), musée entièrement privé situé dans l'État de Tasmanie (Australie) qui a ouvert en 201 I. Cet article analyse la relation entre le MONA (via son expérience de tourisme créatif) et le gouvernement de Tasmanie. Une attention particulière est portée à la façon dont les différents acteurs utilisent le concept d'expérience créative afin d'attirer des touristes aux différents événements et expositions. Le cas du MONA montre que le concept de tourisme créatif est plus complexe que la seule prise en compte d'une approche "créative". ॥ montre, en outre, que l'utilisation d'expériences de tourisme créatif dans les stratégies de marque des destinations doit, pour réussir, être partagée par l'ensemble des parties prenantes. II ouvre ainsi la discussion sur les relations entre les différentes parties prenantes dans le secteur du tourisme créatif.
\end{abstract}

Abstract. The cultural sector is increasingly seen as a potential driver of (tourism) growth by governments, especially in peripheral sub-regions like Tasmania where the once dominant industries have departed. This sector can be a source of local creativity, social inclusion and an attractor of tourists. Occasionally, the creation of an iconic cultural entity serves this purpose with minimal input of public resources. Such a case is provided with the opening of the privately owned and operated Museum of Old and New Art (MONA) in the state of Tasmania, Australia in 2011 . This article analyses the relationship between MONA and its creative tourism experience, and the government of Tasmania. A particular focus is thereby on how those actors use the concept of a place-based creative art experience to attract tourists with events and exhibitions. In this respect, the MONA case shows that the concept of creative tourism is far more complex than just taking a "creative" approach. Moreover, it argues that using creative and cultural tourism experiences for place branding strategies will only be successful if the strategies are mutually agreed upon amongst all stakeholders. In this sense, the article stipulates a discussion on stakeholder relations in the creative tourism sector. 


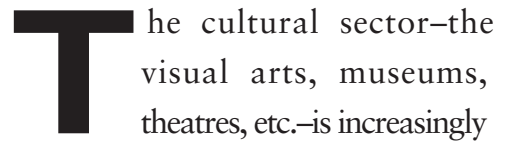
seen as a potential driver of growth by governments and organisations charged with promoting economic development around the world (Kotler and Kotler, 2000; Throsby, 2008). This is particularly the case in regions where the once dominant industries have departed (Bagwell, 2008). The result for such regions can be high unemployment and deserted cityscapes, both of which serve to limit opportunities to attract tourists: often seen as one way economically depressed regions can rebuild. Even so, stimulating the development of a cultural sector that can then be both a source of local creativity and social inclusion, as well as an attractor of tourists, can be expensive and difficult. Occasionally, though, policy makers are provided with an iconic cultural entity that serves their purpose, with a minimal drain on public monies. This has been the case in the state of Tasmania, Australia, with the opening of the privately owned and operated Museum of Old and New Art (MONA) in 2011 ( $c f$. figure 1).

As Australia's smallest (and only island) state, Tasmania is geographically and economically isolated. In a European context it would be considered as a peripheral sub-region. In the past governments have relied on cheap hydro-generated electricity to attract manufacturing industries for employment and economic growth. Recent times have seen service-based industries such as cultural

Figure 1.View OF MONA

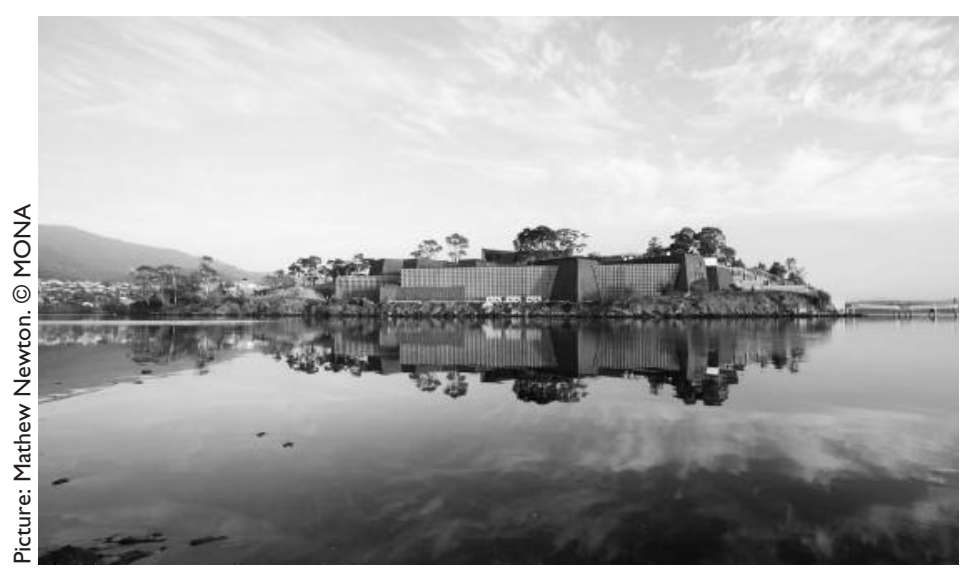

tourism become more important to Tasmania's prosperity (Engberg, 2009). As part of this change in policy direction, Tasmania's government has established art and cultural events, a literary prize and supported various private festivals and events in a move to rebrand the state, as well seeking to attract tourists (particularly in the low season-May to September). It has also now developed a close working relationship with MONA, including providing funding for events and cooperating on exhibitions. MONA has become a "destination" museum, and for the government of Tasmania this is a cause for celebration.

This article analyses the relationship between MONA and the government of Tasmania, and looks at how these actors use the concept of a place-based "art experience" to attract tourists who seek a more creative cultural experience, either as core to their visit or as only a part of another type of visit (Hughes, 2002). From the viewpoint of cultural tourism there needs to be a clearly articulated vision as regards the attributes that can be used as an attractor-cultural tourists require an authentic experience (Smith, 2003), and this no more so than for those seeking an "art experience”. Indeed, it has been recognised that visitors to art museums are different to other cultural tourists (Stylianou-Lambert, $20 \mathrm{I}$ ). Branding MONA as distinctive, as avant-garde, as one man's vision, has allowed it to position itself as different to other cultural attractions in both the state of Tasmania and in Australia. The value of this differentiation is now becoming apparent as the government uses the success of MONA to its own advantage, and incorporating it into its own tourism marketing strategies. Tasmania is now seen as similarly "creative" and "cultural". Significantly, we contend that the public discourse surrounding MONA now comes from a "creative tourism" perspective and is indicative of a broadening of the concept of creative 
tourism beyond "courses and learning experiences" (Richards and Raymond, 2000, p. 15).

\section{Cultural tourism, CREATIVE TOURISM AND THE ART EXPERIENCE}

As the great majority of tourists visiting a country come into contact with some form of heritage, most travel contains some elements of cultural tourism. However, this only applies if a broad sense definition of cultural tourism is used. In a narrow sense, it is a special interest holiday that is solely motivated by cultural interests such as "trips and visits to historical sites and monuments, museums and galleries, artistic performances and festivals, as well as lifestyles of communities" (Medlik, 2003, p. 48). The expected cultural experiences, especially education and curiosity to learn about other people and their culture (Lomine and Edmunds, 2007) are the primary motivation for travelling and are not just a secondary, contingent or ancillary motive for the travels (Douglas, Douglas and Derrett, 200 I).

In the broad sense, a cultural tourist can be defined as "any individual who visits cultural institutions or places such as museums, archaeological and heritage sites, operas, theatres, festivals or architecture while away from home" (StylianouLambert, 20I I, p. 405). Research suggests that these tourists are better educated than the average tourist (Richards, 1996) and have a particular interest in the authenticity and the location of the cultural experience (Smith, MacLeod and Hart Robertson, 2010). A particular form of cultural tourism that attracts certain cultural tourists is arts tourism. Arts tourism "focuses on both visual and performing arts, as well as cultural festivals and events", and includes visitation of galleries, museums, concerts and theatres (Smith, MacLeod and Hart Robertson, 2010, p. 32).

Historically, the mission of a museum, including art museums, is cultural. They give "individuals the opportunity to withdraw from the busy world and to gaze on works of art at their own pace and choice" (Roberson, 2010, p. 77). However, the principal aim of the "destination" museums (e.g. the Guggenheim Museum, Bilbao; the Tate Modern, London) appears to be "the reactivation (and/or diversification) of the economy of their cities" (Plaza and Haarich, 2009, p. 259). At the same time, many new and old museums today try to achieve a high tourist recognition to facilitate regional growth and re-development. It is not surprising that Prentice (200I) suggests that museum are "well-advised to involve themselves locally in appraisive brand marking” (200I, p. 22) and position their institutions as objectively authentic if they want their museums to become landmarks of urban development that contribute considerably to the atmosphere and attraction of a city (Hamnett and Shoval, 2003; Roberson, 2010). This is particularly important for attracting the growing number of tourists who seek authentic cultural experiences.

It is obvious that such issues are much easier for private museums to address than for public museums. Private museums can react to market forces and shape their "product" offering accordingly, while public museums rely far more on government policy, governmental changes and their conservation and education agendas (Cole, 2008). Nevertheless, marketing has become a survival tool for both public and private museums (Lehman, 2009) as it helps to build stronger relationships with existing visitors by developing and promoting exhibitions and programmes that reflect their interests and preferences, and rewarding them for their loyalty and support (Cole, 2008).

Such relationship building is particularly important for visitors to art museums. Stylianou-Lambert (2009) argues that the perception of art museums and consequent visitation or non-visitation is determined by socio-cultural and individual or psychological factors. Socio-culturally different social groups demonstrate different consumption patterns with regards to art museums (Bourdieu, 1986; Bourdieu and Darbel, 199|). However, pure sociological approaches are not sufficient to explain visitation behaviour of people as this is also influenced by the subjectivity of the individual. Roberson (2010) makes the point that the interaction between the individual and art is emotional and personal. Research into the perception of art museums should therefore combine individual characteristics 
with socio-cultural influencers (Stylianou-Lambert, 2009). While there is much work published that analyses and criticises artistic paintings, sculpture and architecture, there is a lack of research in the area of visitors' individual experiences within art museums (Belfiore and Bennett, 2007; Hein, 1998). It is clear, however, that those tourists seeking an immersive, cultural experience are going to respond to an art museum that involves them in a creative and participatory manner (Lindroth, Ritalahti and Soisalon-Soininen, 2007).

The relationship between tourism and creativity has changed dramatically in recent times. Traditional cultural tourism has transformed, moving towards a greater involvement with the everyday life of the destination-an authentic experience-which is one driver for the growing importance of creative tourism (Richards, $201 \mathrm{I})$. Another driver that is particularly pertinent in this case is the fact "many cities are struggling to become more creative, and to present themselves as creative destinations" (Richards and Marques, 20I2, p. 3). Accordingly, UNESCO (2006) defines creative tourism as "travel directed toward an engaged and authentic experience, with participative learning in the arts, heritage, or a special character of a place, and it provides a connection with those who reside in this place and create this living culture" (UNESCO, 2006, p. 3).

Creative tourism itself is closely linked to the increasingly role of both the creative industries and cultural tourism in urban regeneration, which has led to the reconceptualisation of cultural tourism to include creative tourism (Jelincic and Žuvela, 20I2). Creative tourism makes particular use of knowledge, traditions and technologies to provide a basis for cultural heritage development. The main drivers of consumer demand for such experiences include the growing request for the active participation in cultural practices, as well as consumer creativity that is fostered by new forms of interaction channels like social networks and mobile phones (Gordin and Matetskaya, 20 I2). As a consequence, modern museums and art galleries, both public and private, have to adapt to these creative technologies and ideas to stay competitive-indeed, as noted above, they now need to "immerse" their visitors in a creative experience to compete with other leisure and tourism activities.

However, the concept of creative tourism is still vague. Much more research is needed (Tan, Kung and Luh, 2013) in a variety of areas such as the integration of creative tourism with different place branding strategies as "an escape route from the serial reproduction of mass cultural tourism, offering more flexible and authentic experiences" (Richards, 201 I, p. I). In the case of MONA and Tasmania there is an opportunity to investigate how this might occur in an art museum context, something that has not been considered by researchers to date. The relevance of the art museum context to the development of the creative tourism concept is that art museums are almost by definition "creative". In this respect there is much to learn about the concept of "creative tourism" from an analysis of a case that is more complex than simply taking a "creative" approach to tourism.

\section{Method}

The data for this paper is drawn from a longitudinal research project that is tracking MONA through its pre-development stage (starting eighteen months before its January 2011 opening), through its opening, and on to reviews after each year of operation. Within an overall qualitative approach this project follows Eisenhardt's (1989) arguments that theory development and the understanding of phenomena can be achieved using a case study. In this paper, the case study approach is justified, as attempting to understand the interconnections between an art experience, creative tourism and place branding would be difficult without the contextual picture thereby provided (Patton, 1990). More significantly, however, is the fact that MONA is such a distinctive entity in its own right, that it is what Yin describes as a "unique case" (2003, p. 40).

Within the qualitative approach an exploratory design was followed, with a major aim being to triangulate the available data. As Mason (2002) has stated, the aim of triangulation is to "seek to corroborate one source and method with another ... [and to] enhance the quality of the data" (2002, p. 33). In respect to the MONA 
organisation, the research design utilised interviews with six key staff (managerial, curatorial and marketing), participant observation (site visits, event attendance, etc.), and analysis of corporate publications, media statements and data from their websites and their social media. Two of the MONA staff involved have been interviewed twice, with a two year period between interviews to allow for a longitudinal perspective. Codes are used here for any quotes from the staff.

In this study a semi-structured approach to the interviews was chosen. Babbie (2005) notes the inherent flexibility in this approach as one of its major advantages. There is an expectation that the views of the interviewee will be more freely expressed when the format of the interview is more flexible and openended than where the interview style is regulated and confined to a standard set of questions or a survey (Flick, 2002). The observation technique was unstructured, as the field visits aimed "to record in as much detail as possible ... with the aim of developing a narrative account" (Bryman and Bell, 2007, p. 283) which could be used as an additional method to support further triangulation of data. The analysis of annual reports, websites, and additional marketing material was carried out using content analysis techniques. Content analysis is an established research method that has been used in various areas of social science, including business, since the middle of the last century (Neuendorf, 2002).
With a view to further triangulating the MONA data and to provide insight into the motivations of the Tasmanian government, an extensive survey of published material was also undertaken. Secondary data, such as public statements, reports, websites and marketing collateral from the Tasmanian government and linked semi-governmental organisations, was gathered for analysis. It is felt that a richness and depth was gained with an analysis of the multiple sources of data that allowed an assessment and analysis of both the MONA and government positions and therefore provide a broad perspective of the phenomena under study (Bryman and Bell, 2007).

In this research study analysis of the data was carried out with the assistance of the qualitative data analysis software package NVivo 9.0. Interview transcripts, field notes and text versions of the various secondary data sources were imported into the software. After Miles and Huberman (1994) the data analysis commenced with a preliminary set of "codes" based on the research aims and the key factors apparent from the literature review. As Robson and Hedges (1993) advise, a process of revisiting the data was then adopted, whereby the data were continually re-examined and re-evaluated. The researchers were then able to refine and revise the codes as the analysis progressed, with three major themes becoming apparent. These themes form the basis of the discussion and analysis section below. Before that we introduce MONA.

\section{THe Museum of Old and New Art}

MONA is an unusual entity. Firstly, it is a long way from the art capitals of the world, London, Paris and New York. The privately owned art museum-unusual in Australia's museum sector-at the core of the corporate brand MONA has a significant though small collection. It opened in January 2011 at a reported cost of AU\$70 million (€48.2 million) and has free entry for local residents-national and international visitors currently pay an AU\$20 (€13.8) fee. John Kaldor, a member of the International Committee of New York's Museum of Modern Art, has stated that "MONA has been a watershed in the way that art is understood by the general public" (cited in Flanagan, 20।3, p. 52).

A key point in understanding MONA is the fact it has been established and is funded by millionaire David Walsh, who has been described in the media as "a professional gambler", a "rabid atheist", and a "university drop-out and autodidact" (Coslovich, 2007, p. 5). Despite the conjecture in the media about David Walsh, he has a vision for MONA that is quite clear, and very personal. Of course private museums are by definition idiosyncratic. David Walsh frequently stresses the subjective nature of MONA, and has been quoted as saying: "I've got a soapbox that I want to stand on. I've got some things to say. I'm the kind of person who would scream obscenities into the wind in Hyde Park if I 
was English, but I'm not English" (cited in Schwartzkoff, 2009, p 12).

Much of the art in MONA's collection is evidence of Walsh's stance. He owns Chris Ofili's The Holy Virgin Mary, which has Mary as a black woman surrounded by female genitalia and elephant dung. He also owns a version of the Belgian artist Wim Delvoye's Cloaca Professional, a machine that mimics the human digestive system to produce what looks and smells like faeces. A recent exhibition (June 2011-February 2012), "Theatre of the World", was curated by French art expert JeanHubert Martin and adopted a radical stance in relation to curatorial practice. In an excellent example of the cooperation between the Tasmanian government and MONA, the exhibition ${ }^{(1)}$ combined antiquities and contemporary works from both the MONA and the stateowned Tasmanian Museum and Art Gallery collections. Martin stated that "It is all about the works -known or unknown-shown in an unexpected way. It's all about surprise $^{(2)}$ ". David Walsh, as well as the other senior staff that have media contact, frequently note the "challenging" nature of the work in the collection, which serves to reinforce the avant-garde branding evident in much of MONA's marketing communications.

Significantly, MONA is not just the art museum. Under the corporate brand "MONA" sits a range of luxury products. The original product of the corporate brand was Moorilla wines, now rebranded with a more "edgy", more sophisticated positioning, complete with sensual images on the labels. There is also the successful boutique beer brand Moo Brew, with labelling designed by Australian artist John Kelly and a distinctive and very non-beer champagne-shaped bottle. At the cellar door for both these products is a restaurant called The Source. In addition, there are eight luxury accommodation apartments that feature work from the art collection, designer furniture and controversial architecture. The Pavilions, as they are called, sit on the edge of the Derwent River, and cost AU\$7.6 million (€5.24 million) to build. The final products within the MONA umbrella brand are a number of art/music festivals and cultural events: primary amongst these are MONA FOMA (Festival of Music and Art), or MOFO and Dark MOFO, a winter festival which commenced in 2013 (see a review of the festival: Northover, 2013). Having a range of complementary products, many of which are situated on the MONA property, is a key part of MONA's overall brand strategy, which aims to "immerse" the visitor in a "MONA experience".

One problem for MONA is that the market for a "challenging" art museum, and the associated complementary luxury brands, is relatively small, particularly in a country with a population the size of Australia's. It might be said that MONA's opportunities for growth in Tasmania is even smaller. Also important is the fact that art and cultural organisations need to be product driven. If they are not they risk their artistic integrity, the very thing that challenges their target markets (Colbert et al., 2007). Who, then, is the target market that will take MONA into the future? David Walsh has been quoted as saying: "I want to target the world, but I want to target a very small percentage that might be interested in this subversive, adult kind of Disneyland... [They] might come from New York or Hobart, and if they come from New York, they'll justify the long trip and fairly large expense because the specific experience might have something to say to them" (cited in Strickland, 2009, p. 38).

Clearly, the cultural tourist, be they Australians travelling to Tasmania, or international visitors travelling to Australia, are a significant and desirable market for MONA (and indeed for Tasmania). Significantly, MONA's long-term future is linked to this potential market. Local visitation will not be enough: MONA sources have stated they are working towards a model of MONA being self-sustaining in five years (Interviewee $3 / 2$ ). It is, then, in MONA's interests to forge relationships with government to achieve the common goal of attracting the cultural tourist to Tasmania.

\section{Discussion and Analysis}

While the three major themesMONA as creative, immersive activity (what MONA does); MONA as atmosphere and place (what the 
government of Tasmania does); and MONA as Tasmania/Tasmania as MONA (how the two link together)-can be clearly articulated, it should be noted that each is interconnected within the narrative that is the relationship between the two actors, the Tasmanian government and MONA itself. Indeed, this interconnectedness is a feature of the relationship. Certainly, destinations/regions/places that brand themselves as creative need to be aware of the difference between cultural tourism and creative tourism, as noted in the section above. The implications for government relate quite clearly to a policy agenda wider then simply "attracting" tourists. There is a view that for place branding to be successful it must involve all stakeholders (Hankinson, 200I). In a creative tourism context this means that: "The look of the city, the services offered, the engineering communications, the education system and the transportation system could all be perceived as a source of inspiration if tourists are moved by what they see" (Gordin and Matetskaya, 2012, p. 57).

As will be demonstrated in the following discussion, the idea of "immersion" in Tasmania is deliberately linked to immersion in the art (and broader cultural) experiences offered by MONA.

\section{MONA as creative, immersive activity}

The consumption of cultural products has become less engaging for the more experienced and deman- ding tourist (Richards, 2010)-it is frequently seen as a passive activity. In contrast, as Gordin and Matetskaya (2012) note, the main goal of creative tourism is "experiencing things first-hand, living through new emotions, acquiring new knowledge and skills through engaging in creative activity shared with fellow tourists, and through interactions with the locals ... [and] consuming the local cultural products and events" (Gordin and Matetskaya, 2012, p. 57).

With this in mind the aim of actively involving visitors in the MONA experience is a deliberate strategy to engage the visitor. As one MONA staff member noted: “... we're now looking at everything that happens on that peninsula [Berridale] as being MONA. So it doesn't matter if it's the wine, the beer, the accommodation, any music events we have there, live gigs, or whatever, events of any sort, functions, and the museum itself, are all now going to be called MONA" (Interviewee 1/2).

The reason that strategy can work is that MONA is an "umbrella" brand, that incorporates a number of different, complementary cultural "products" that are then used to immerse visitors, both local and tourist, in a full MONA creative experience. In other words, the actual site of MONA has a range of different "attractions" on the one site that appeal to the cultural tourist. Importantly, and certainly in a marketing/branding sense, these attractions are entwined with the personality of David Walsh. As one inter-
Figure 2 - MOFO

PROGRAM 2014 WEBSITE IMAGE

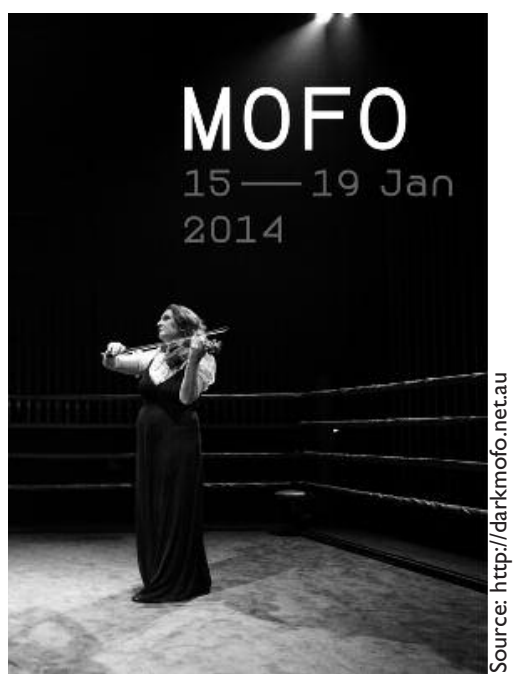

viewee noted: "MONA is his, it's his taste, it's his sort of architecture, it's... well, every artwork is chosen ultimately by him, and ultimately it will be placed according to his wish. So in a way, one is his guest" (Interviewee 1/2).

While the museum itself is the main focus of visits to the MONA location, central to the MONA strategy is a series of events or festivals that allow visitors to involve themselves in different aspects of the MONA experience. MONA FOMA, in particular, has done much to attract cultural tourists, and allow an experience not available in other festivals (Lehman, 2012) (cf. figure 2). Further, it is considered by MONA to be both a promotional tool of the umbrella brand (Interviewee 2), and: "... part of that genuine [MONA] experience: it's there, people can enjoy it or hate it, but it showcases the taste of David and a 


\section{Figure 3 - Members of the TSO Chorus from the staircase inside Hobart's Museum of Old and New Art during the Symesthesia 2012 festival}

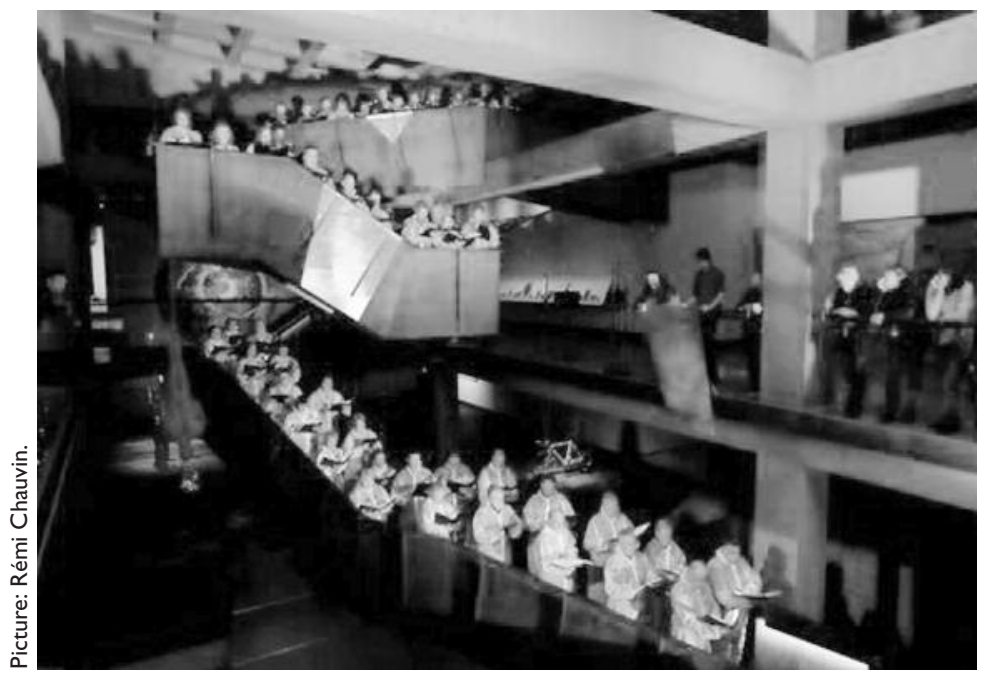

taste of the diversity he's into" (Interviewee 1/1).

However, while MONA FOMA, and the very successful Dark MOFO noted above, occur throughout the city of Hobart (and beyond) a good example of how the "immersion" strategy works is when the event takes place completely within the MONA grounds, either inside the actual museum or out on one of the open areas on the property. The following two events are indicative of the types of events used by MONA to go beyond visitors simply "watching".

\section{- Example 1:}

\section{Synaesthesia concert event}

First held in November 2012, and now being performed again in 2014, the Synaesthesia concert involves the Tasmanian Symphony Orchestra playing throughout the MONA museum complex ( $c f$. figure 3 ). This immersive musical and visual event is devoted to and inspired by "synaesthesia", a term that "... describes the phenomenon where a person experiences idiosyncratic multi-sensory responses to stimuli, most commonly music, or particular letters or words such as the days of the week" (Giles, 20I2).

Various musical performances take place throughout the museum. As was noted in the media after the first concert: "For the best part of the weekend, 400 people were left to wander through the bowels of MONA for an immersive festival of colour and music" (Wilson, 2012). Guests also dined on gourmet food and wine as part of the $\mathrm{A} \$ 600(€ 420)$ ticket price.

\section{- Example 2:}

Tea Ceremony

One of the activities available to visitors to the MONA site is the Tea Ceremony. The description from the MONA website best describes the experience offered: "Immerse yourself in chado ('the way of tea') and take part in an ongoing performance artwork made by Rirkrit Tiravanija especially for The Red Queen exhibition at MONA. The work revolves around the centuriesold Japanese chado, a precisely disciplined tradition informed by Zen Buddhism for preparing and serving matcha (powdered green tea). As a participant, you will be guided by tea master Allan Halyk to the heart of chado: rigorous simplicity, and awareness of the moment" (MONA, 2013a).

Space does not permit further examination of other MONA events that involve visitors in a creative experience $^{(3)}$. One final, and crucial, aspect of the immersive nature of MONA the museum is the absence of the traditional, interpretive labeling of the artworks. In MONA this has been replaced by the much talked about "O" device. Essentially an electronic guide to MONA, that includes essays or interviews from curators, the artsists, and David Walsh himself, as well as maps and photos. It is based on an iPod Touch that runs custom software and is housed in a specially designed case. According to Pearce (20।2), "Walsh was frustrated with this standard wall label approach of museums and he also wanted MONA's visitors to be able to rate artworks-to 'love' or 'hate' them". There is also a button that brings up a list of nearby artworks, which allows the visitor to literally immerse themselves 
whilst on site. To further reinforce the experience, visitors can download and view a map of their visit via the MONA website once they have returned home. This last point is particularly significant from a tourism marketing perspective as it allows a continuation of the experience by further interacting with the location after they have left (Williams, 2006).

\section{MONA as atmosphere and place}

Richards and Marques (20/2) have stated that creative tourism can have a role as a source of atmosphere for a destination. By this they mean that the creative nature of the tourism experience becomes an integral part of the destination, where "visitors, service providers and the local community exchange ideas and skills and influence each other in a synergetic way" (Richards and Marques, 20I2, p. 4). Similarly, one of the distinct modes of implementation of creative tourism strategies identified by Richards (2010, p. 84) is "using creativity as a backdrop for tourism”. It was noted above that successful place branding involves the cooperation of all stakeholders (Hankinson, 200I). With this in mind the use of MONA and its perceived attributes and benefits becomes important in the language used to market Tasmania by various government entities.

Once again, space does not permit discussion of the full range of examples, but here the comments concerning the Dark MOFO festival (cf. figure 4) illustrates the point.

\section{Figure 4. Dark MOFO 2013 website IMAGE}

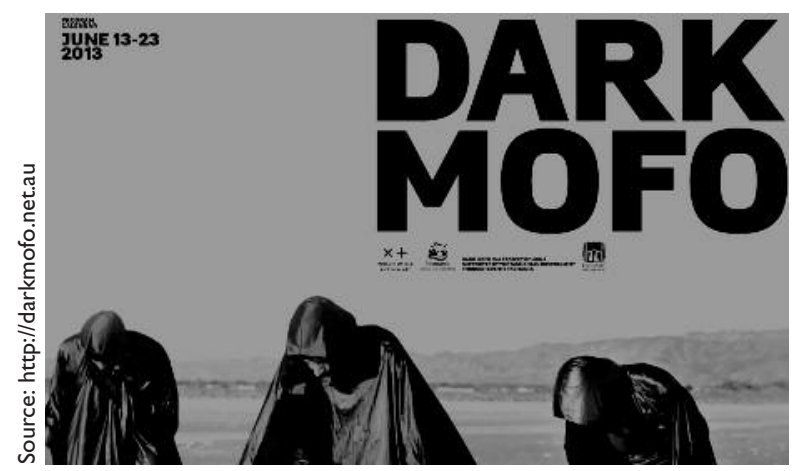

\section{- Example 1:}

Premier of Tasmania,

Lara Giddings, and Scott Bacon,

Minister for Tourism,

launching Dark MOFO

"This investment will help support jobs in the hospitality sector while providing a much needed economic boost to the broader business community during the traditionally quiet winter period. It is exciting to see the organisers of existing and proposed events sharing ideas and working together to create a unique experience. This sort of dedication and collaboration within our arts and cultural sector is one of the reasons Tasmania now enjoys a reputation as a thriving cultural destination" (Government of Tasmania, 20I2).

\section{- Example 2:}

Events Tasmania (a governmentfunded organisation) reports on Dark MOFO

"Dark MOFO (13-23 June, 2013) has been an outstanding success. Dark MOFO's Winter Feast at Princes Wharf Shed No.1 [in Hobart] made a stunning debut on the Tasmanian culinary calendar, the Winter Feast drew almost 30,000 people to its fires across three nights, combining the best Tasmanian food, wine, cider and whisky with music, art and guest chefs. Tourism Industry Council Tasmania chief executive Luke Martin said there had been a certain 'wow factor' about the Winter Feast that required further analysis. 'One of the things that I took out of the Winter Feast was that it created such a strong atmosphere in the shed that really built on the theme and had a consistent branding across all the stalls" (Events Tasmania, 20।3).

What is clear in these brief examples is that the government links the present strengths of Tasmania-its food, wine, location and cultural assets-with the increasingly popular arts and cultural festivals curated by MONA. While the economic imperative of supporting hospitality and tourism ventures during the quiet winter season is obviously a major driver of the government support, it is also equally clear that these cultural events add to the "atmosphere" of creativity 
about which a creative tourism strategy can be built (Richards, 20II). Equally, there is an interconnectedness, a symbiosis almost, between the government of Tasmania and MONA.

\section{MONA as Tasmania/ Tasmania as MONA}

In many ways both the government and MONA use "MONA" in various ways to promote the creative nature of themselves-simultaneously incorporating each other into their own discourse. The key issue in the relationship between the Tasmanian government and MONA relates to “place". Both entities use MONA as an attribute of place branding: the government stressing the benefit to Tasmania of MONA actually being here in respect to cultural tourism; and MONA itself, on the one hand claiming its location is irrelevant ("We are here because David Walsh lives here-our art could be shown anywhere" [Interviewee 3/2]), and on the other, needing to do all it can to encourage visitation from interstate and international tourists, which includes clearly recognising that the attributes of Tasmania are important to the MONA brand: "... if we were in Melbourne or Sydney I just don't... I can't see that the same approach to MONA would have occurred. There's something about its location, the ferry, there's just a whole part of rediscovery of Tasmania, that sort of process" (Interviewee 3/2).

Part of MONA's branding is that they wish to be seen as avant-garde, and only in existence as part of David
Walsh's “vision”. As just noted, MONA staff interviewees state that the museum could be anywhere: "This project happens to exist in Tasmania, outside of Hobart. It could occur in the middle of the desert in New Mexico" (Interviewee 3/1). But they also acknowledge that their products-art museum, wine, etc.-will not be sustainable with Tasmania as the only market (Interviewee 1/2). In some ways they appear to avoid using the attributes of Tasmania as part of their branding, though using remoteness as a drawcard. However, their position as being different to other museums in Australia echoes the Tasmanian government's place branding strategy. For their part the Tasmanian government has done a considerable amount to support MONA in a restricted economic climate. MONA FOMA and Dark MOFO are supported by Events Tasmania, the government organisation responsible for delivering the State government's event tourism strategy. International and national journalists and travel writers have been sponsored by Tourism Tasmania, the government tourism department, and Tourism Australia at the national level, to visit and write on MONA.

As has been noted in the media (e.g. Engberg, 2009), the government consider themselves fortunate in having such a cultural icon built in the state without direct government funding-as the then Economic Development Minister Paula Wriedt said at the announcement of MONA's construction: "MONA has the potential to become a real icon for this state ... It embodies the highest level of entrepreneurialism and creativity that exists in the Tasmanian community" (cited in Neales, 2008). Three years later, in 2011, the Premier of Tasmania, Lara Giddings, said this: "The Arts are an economic driver for our state ... The opening of David Walsh's Museum of Old and Modern Art in January this year has also helped to secure Tasmania's place on the international stage and showcase the high quality and diverse arts experiences that our State has to offer"(Government of Tasmania, 201 I).

Of course, it could be said that politicians make such statements regularly. However, the MONA brand is now firmly entwined with that of Tasmania, as this quote from Premier of Tasmania, Lara Giddings, in the 2013 MONA FOMA Program illustrates: "MONA FOMA is an exemplar of cultural tourism in the State... We recognise and support the significant role it and MONA are playing in developing this market... Tasmania is a creative community... we all benefit from the raising of the Tasmanian profile as an exciting location for arts activity” (MONA, 2013b).

The results for MONA and the state have been impressive. Visitor numbers have exceeded expectations-in the year ending June 2012, $25 \%$ of all visitors to Tasmania (210,300) visited MONA (Tourism Tasmania, 2012a). By the end of the same year more than 500,000 people had visited MONA since its opening 
(Interviewee 3/2). Significantly, these visitors are primarily cultural tourists. Within Tasmania's tourism industry, cultural tourism related to the arts plays a vital role as "just under half of all visitors participated in an arts experience" (Tourism Tasmania, $2012 b, p .4)$. This is reflected in Tourism Tasmania's Arts Tourism Strategy 2012-2015. This document defines arts tourism as a sub-set of cultural tourism which includes visitor experiences that are based on: "performing arts, visual arts, literature, craft/design and music; creative tourism - the active participation in the creative process of the arts; ... Arts tourism also includes events related to the above activities as well as museums" (Tourism Tasmania, 20।2b, p. 3).

There is, then, a clear connection in this case between the cultural experience entity that is MONA, the cultural tourism as a source of economic development (and the "creative" aspects that drive participation), and the strategies of public policy makers in Tasmania. The use of place by the Tasmanian government and MONA is crucial to this case, and perhaps indicative of the benefit of linking policy strategies to clearly articulated place branding attributes. In this case these centre around the "creative" as the central message in the discourse.

\section{Conclusion}

This article has analysed the relationship between the government of Tasmania and the Museum of Old and New Art (MONA) and how both have used the notion of a placebased "art experience" to attract tourists who seek a more creative cultural experience. Certainly, such tourists can be a lucrative market: in Australia it has been acknowledged that the arts and cultural sectors contribute to the public good through economic development, cultural value and engagement and social impact (Cultural Ministers Council Statistics Working Group, 20 I0). In the UK a large study discussed the economic, social and creative impacts of museums and art galleries, noting that such institutions "play leading roles in encouraging civic development and economic regeneration within society" (Travers, 2006, p. 6). Interestingly, though there has been considerable research on the impact of "destination" museums-the "Bilbao Effect" being the most notable case in point (see for example, Plaza and Haarich, 2013)-there has been little research on the role a privately owned art museum such as MONA might play in attracting cultural tourists. This study represents a first step in investigating this phenomenon.

Certainly, MONA is an example of a private art museum (and a portfolio of products and brands) that has successfully managed to become such a destination museum despite its remote location in the Tasmanian capital of Hobart in Australia. There is no doubt that MONA reinforces the argument that creative art museums are about unsettling assumed relationships between seeing and believing by challenging visitors perception of the world (MacRae, 2007), while at the same time becoming a vitally important tourist attraction. Central to the success is the strategic use of immersive events and activities that involve the visitor in the range of MONA brands/products. The implications for other cultural tourism organizations is that a "creative" experience is possible outside the common view that "creative" always means visitors making or learning about something (e.g. participating in art making or courses). In the case of MONA it is the concept of co-creation by immersion in the events and exhibitions that is important-in effect, tourists are surrounded by creativity. Of course, this means that for organisations seeking to replicate MONA's success events need to be carefully chosen to achieve this aim.

Furthermore, the factor that moves the MONA experience beyond what Richards calls "mass cultural tourism" (201 I, p. I) is an integration of place branding strategies with creative tourism. These strategies have been strengthened by the part the government of Tasmania has played in supporting MONA activities and events. The implications of this for other jurisdictions is clear-there must be considerable cooperation and communication between the policy makers in government and the creative tourism operators. It is important that both share the same objectives for the collaboration, and that this interconnectedness is apparent in the 
public statements of both parties. In Tasmania the key word is "creative", and both MONA and the Tasmanian government incorporate it into their discourse.

Overall, then, the case of MONA has shown that the concept of creative tourism is more complex than simply taking a "creative" approach. As has been noted, we contend that the public discourse in Tasmania, and in the Australian media, surrounding MONA now comes from a "creative tourism" perspective. That said, more research is still needed to further understand the role the "creative" can play in tourism. Smith (2003) has noted that there has been a traditional reluctance on the part of both the arts and tourism sectors to "embrace joint initiatives" (2003, p. 38). With this in mind future research in creative tourism would benefit by investigating the ways in which arts organizations could cooperate with tou-

\section{Notes}

(I) This exhibition travelled to Paris, running from 19 October 2013 to 19 January 2014

at La Maison rouge: "Théâtre du monde"

[http://wnw.lamaisonrouge.org/cgi?usr $=k 5 q 8 j$ ms9qu\&lg=fr\&pag $=2334 \&$ tab $=108 \&$ rec $=25$ \&frm=0\&id=393 I \&flux=629449 I l ] .

(2) Cited in "MONA: a whole new world awaits, kaleidoscope of dreams, imagination and emotion", The Mercury, 2012.

(3) See, for instance, the MONA Market [http://www.momahobart.net.au]. rism operators, or indeed how they might adopt a model similar to MONA's-e.g. using immersive, creative events-as part of their activities.

Similarly, it is clear that place branding strategies that emphasise the creative and cultural, and that are mutually agreed amongst stakeholders, are vital to the success of creative tourism. For this reason there is much that could be learned by research into stakeholder relations in the creative tourism sector. There is considerable work done on stakeholder management in organizations from other sectors (see, for example, Verbeke and Tung, 20/3), but very little that explores how those involved in cultural tourism interact. The same could be said of the interactions between creative tourism destinations and the tourist. As has been shown, at its core MONA is an authentic art experience that resonates with the creative cultural tourist. Furthermore, without such authenticity success is difficult to achieve for arts and cultural products (Castéran and Roederer, 20/3). It could, then, be invaluable to extend research into the role of "authenticity" in all aspects of creative tourism. Research questions such as the following suggest themselves: When do tourists see themselves as creative tourists? What is a "creative" experience for an art tourist? How do tourists choose between creative tourism destinations? How significant is the concept of "immersion" introduced here in relation to tourists measuring authenticity? Clearly, the case of MONAas a nexus between an art experience and creative tourism-has broadened the definition of creative tourism well beyond Richards and Raymond's (2000, p. 15) “courses and learning experiences", and there is now much more to be discovered about the concept.

\section{Références bibliographiques}

\footnotetext{
EART R. BABBIE, The Basics of Social Research ( $3^{\text {rd }}$ edn),

Thomson/Wadsworth, 2005 ( I $^{\text {st }}$ edn 1999).

SUSAN BAGWELL, "Creative clusters and city growth",

Creative Industries Journal, vol. I, $n^{\circ}$ I, 2008.

Eleonora BELFIORE and Oliver BENNETT, "Determinants of impact: towards a better understanding of encounters with the arts", Cultural Trends, vol. 16, n 3, 2007.

Pierre Bourdieu, Distinction: A Social Critique of the Judgement of Taste, Routledge, 1986 (orig. edn La Distinction : critique sociale du jugement, Minuit, 1979).

Pierre Bourdieu and Alain DarbeL, The Love of Art: European Art Museums and

Their Public, Polity Press, 1991 (orig. edn L'Amour de l'art: les musées d'art européen et leur public, Minuit, 1966).

Alan BRYMAN and Emma BeLL, Business Research Methods ( ${ }^{\text {nd }}$ ed.),

Oxford University Press, 2007.
} 


\section{DOSSIER • TOURISME CRÉATIF}

Herbert CASTÉRAN and Claire ROEDERER, "Does authenticity really affect behavior? The case of the Strasbourg Christmas Market",

Tourism Management, vol. 36, June 2013.

François COLBERT et AL, Marketing Culture and the Arts ( $3^{\text {rd }}$ ed.), Presses HEC, 2007 ( I $^{\text {st }}$ edn 1994).

Denise COLE, "Museum marketing as a tool for survival and creativity: the mining museum perspective", Museum Management and Curatorship, vol. 23, n², 2008.

Gabriella CosLovich, "The collector", The Age, "Arts",

I 4 April 2007 [http://www.theage.com.au/news/arts/thecollector/2007/04//2/1 17597/2602 |6.html].

CUltural Ministers Council Statistics Working Group, Vital Signs: Cultural Indicators for Australia ( I $^{\text {st }}$ edition for consultation), National Centre for Culture and Recreation Statistics, Australian Bureau of Statistics, 2010.

Norman Douglas, Ngaire Douglas and Ros Derrett, Special Interest Tourism: Context and Cases, John Wiley \& Sons, 2001.

Kathleen M. EISENHARDT, "Building theories from case study research", Academy of Management Review, vol. 14, n 4, 1989. Juliana ENGBERG, "Southern discomfort: Tasmania's art scene", Monthly, December 2008-January 2009

[http://www.themonthly.com.au/art-juliana-engberg-southern-discomfort-tasmania-s-art-scene-1336].

Events TASMANIA, "Dark MOFO Long Nights, Bright Lights", 2013 [http://www.eventstasmania.com/news/20I3/dark_mofo_-

_long_nights,_bright_lights].

Richard FLANAGAN, "Tasmanian devil: a master gambler and his high-stakes museum", The New Yorker, 21 January 2013 [online]. Uwe FLICK, An Introduction to Qualitative Research ( $2^{\text {nd }}$ edn), Sage Publications, 2002.

Josephine GILES, "Synaesthesia; how you perceive it",

Aussietheatre.com, 2102 [http://aussietheatre.com.au/reviews/synaesthesia-how-you-perceive-it].

Valery GORDIN and Marina MATETSKAYA, "Creative tourism in Saint Petersburg: the state of the art", Journal of Tourism Consumption and Practice, vol. 4, n.2, 2012.

GOVERNMENT OF TASMANIA, "Maintaining Investment in the Arts Media release", 16 June, 2011.

GOVERNMENT OF TASMANIA, "Dark Mofo A new winter festival for 2013 Media release", 22 October, 2012.
Chris HamnetT and Noam SHOVAL, "Museums as 'Flagships' of Urban Development", in Lily M. HOFFMAN, Dennis R. JUDD and Susan S. FAINSTEIN (eds), Cities and Visitors: Regulating People, Markets, and City Space, Blackwell, 2003.

Graham HANKINSON, "Location branding: a study of the branding practices of 12 English cities", Journal of Brand Management, vol. 9, n² 2, 2001.

George E. Hein, Learning in the Museum, Routledge, 1998.

Howard L. HUGHES, "Culture and tourism: a framework for further analysis", Managing Leisure, vol. 7, $n^{\circ}$ 3, 2002.

Daniela Angelina JELINCIC and Ana ŽUvELA, "Facing the challenge? Creative tourism in Croatia", Journal of Tourism Consumption and Practice, vol. 4, $n^{\circ} 2$, 2012.

Neil KotLer and Philip KotLer, "Can museums be all things to all people? Missions, goals, and marketing's role", Museum Management and Curatorship, vol. 18, n³, 2000.

Kim LeHMAN, "Museums and the modern public: a marketing context", Journal of Arts Management, Law, and Society, vol. 39, n², 2009.

Kim LeHMAN, "Connecting to the cultural consumer:

The MONA FOMA experience", in Gary Armstrong, Stewart Adams, Sara M. Denize and Philip Kotler, Principles of Marketing ( $5^{\text {th }}$ ed., Frenchs Forest) Pearson Australia, 2012 ( It $^{\text {st }}$ edn 1980).

Kaija LINDROTH, Jarmo RITALAHTI and Tuovi SOISALON-SOININEN, "Creative tourism in destination development", Tourism Review, AIEST, vol. 62, n 3-4, 2007.

Loykie LominE and James EDmunds, Key Concepts in Tourism, Palgrave Macmillan, 2007.

Christina MACRAE, "Using sense to make sense of art: young children in art galleries", Early Years, vol. 27, n. 2, 2007.

Jennifer MASON, Qualitative Researching ( $2^{\text {nd }}$ ed.),

Sage Publications, 2002 (I ${ }^{\text {st }}$ edn 1996).

Slavoj MedLIK, Dictionary of Travel, Tourism and Hospitality ( $3^{\text {rd }}$ edn), Butterworth-Heinemann, 2003 ( $\left.\right|^{\text {st }}$ edn 1993).

Matthew B. Miles and A. Michael Huberman, An Expanded Sourcebook: Qualitative Data Analysis (2 $2^{\text {nd }}$ ed.), Sage Publications, 1994 ( ${ }^{\text {st }}$ edn 1984). MONA, "What's on Tea ceremony", 2013a [viewed 24 October 2013: http://www.mona.net.au/what's-on/tours/].

MONA, 2013 MONA FOMA Program, 2013b.

S. NeALES, "Magnificent obsession", The Mercury,

6 September: Weekend, B06, 2008.

Kimberly A. Neuendorf, The Content Analysis Guidebook,

Sage Publications, 2002. 
Kylie NORTHOVER, "Dark days in which art bares the soul",

The Sydney Morning Herald, I June 2013

[http://www.smh.com.au/entertainment/music/dark-days-in-which-art-baresthe-soul-20 I3053I-2ng4f.html]

Michael QUINN PATTON, Qualitative Evaluation and Research Methods ( $2^{\text {nd }}$ ed.), Sage Publications, 1990 ( ${ }^{\text {st }}$ edn 1980).

Rohan PEARCE, "Why MONA went mobile: the technology behind Hobart's Museum of Old and New Art", Computerworld, 25 December 2012

[http://www.computerworld.com.au/article/print/444906/why_mona_went_mo bile_technology_behind_hobart_museum_old_new_art]].

Beatriz PLAZA and Silke N. HAARICH, "Museums for urban regeneration? Exploring conditions for their effectiveness", Journal of Urban Regeneration and Renewal, vol. 2, no. 3, 2009.

Beatriz PlAZA and Silke N. HAARICH, "The Guggenheim Museum Bilbao: between regional embeddedness and global networking", European Planning Studies, 2013 [published online: 12 July 20 I3].

Richard PRENTICE, "Experiential cultural tourism: museums and the marketing of the New Romanticism of evoked authenticity", Museum Management and Curatorship, vol. 19, n. I, 2001.

Greg RICHARDS, Cultural Tourism in Europe, CAB International, 1996.

Greg RICHARDS, "Creative tourism and local development", in R. WURZBURGER, T. Aageson, A. Pattakos and S. Pratt (eds), A Global Conversation. How To Provide Unique Creative Experiences for Travellers Worldwide (originally presented at the 2008 Santa Fe \& UNESCO International Conference on Creative Tourism, Santa Fe USA), Sunstone Press, 2010.

Greg RICHARDS, "Creativity and tourism: the state of the art", Annals of Tourism Research, vol. 38, n. 4, 2011.

Greg RICHARDS and Lénia MARQUES, "Exploring creative tourism: editors introduction", Journal of Tourism Consumption and Practice, vol. 4, n. 2, 2012.

Greg RICHARDS and Crispin RaYMOND, "Creative Tourism", ATLAS News, vol. 23, 2000.

Donald N. ROBERSON, "Free time in an art museum: pausing, gazing and interacting", Leisure Sciences, vol. 33, n. I, 2010.

Sue RoBson and Alan HedGes, "Analysis and interpretation of qualitative findings. Report of the MRS Qualitative Interest Group", Journal of the Market Research Society, vol. 35, n. I, 1993.

Louise SCHWARTZKOFF, "Art lovers are sharing their passion through private galleries", Sydney Moming Herald, 31 July, 2009.

Melanie K. SMITH, Issues in Cultural Tourism Studies, Routledge, 2003.

Melanie K. SMITH, Nicola E. MACLEOD and Margaret HART Robertson, Key

Concepts in Tourist Studies, Sage Publications, 2010.
K. STRICKLAND, "Cutting Edge”, Life \& Leisure: Luxury (a supplement to the Australian Financial Review), n०10, Oct-Dec, 2009.

Theopisti StYLIANOU-LAMBERT, "Perceiving the art museum", Museum Management and Curatorship, vol. 24, n² 2, 2009.

Theopisti StYlianOU-LAMBert, "Gazing from home:

Cultural tourism and art museums", Annals of Tourism Research, vol. $38, n^{\circ} 2,2011$.

Siow-Kian TAN, Shiann-Far KUNG and Ding-Bang LUH, "A model of 'creative experience' in creative tourism", Annals of Tourism Research, vol. 41, April 2013.

David THrosBy, Creative Australia: The Arts and Culture in Australian Work and Leisure, The Academy of the Social Sciences in Australia, 2008.

TOURISM TASMANIA, "MONA first twelve months of TVS data", 2012a [http://www.tourismtasmania.com.au/_data/assets/pdf_file/0 005/I88 I5/mona_stats_2012.pdf].

TOURISM TASMANIA, Arts Tourism Strategy 2012-2015, Tourism Tasmania, 20 I2b [http://www.tourismtasmania.com.au/_data/assets /pdf_file/00|5//8|23/arts_strategy_20|2.pdf].

Tony Travers, Museums and Galleries in Britain: Economic, social and creative impacts, National Museum Directors' Conference and Museums, Libraries and Archives Council, December 2006. UNESCO, Towards Sustainable Strategies for Creative Tourism, Discussion Report of the planning meeting for the 2008 International Conference on Creative Tourism (Santa Fe, New Mexico, USA), UNESCO Creative Cities Networks, 2006.

Alain VERBEKE and Vincent TUNG, "The future of stakeholder management theory: a temporal perspective", Journal of Business Ethics, vol. $112, n^{\circ} 3,2013$

Alistair WILLIAMS, "Tourism and hospitality marketing: fantasy, feeling and fun", International Journal of Contemporary Hospitality Management, vol. 18, n 6, 2006.

Asleigh WILsON, "Tasty sounds in glorious colour", The Australian, 6 November 2012 [http://www.theaustralian.com.au/arts/tastysounds-in-glorious-colour/story-e6frg8n6- I 2265 | I 007838]. Robert K. YIN, Case Study Research: Design And Methods (3rd ed.), Sage Publications, 2003 ( Itt $^{\text {edn 1984). }}$ 